\title{
Combined multiplex and monoplex RT-PCR as a reliable and cost-effective method for molecular diagnostics of pediatric acute lymphoblastic leukemia
}

\author{
M. SKORVAGA ${ }^{1}$, E. NIKITINA ${ }^{1,2,3}$, A. KOLENOVA 4 , J. PUSKACOVA ${ }^{4}$, M. LEITNEROVA ${ }^{5}$, L. COPAKOVA ${ }^{5}$, IGOR BELYAEV ${ }^{1, \star}$
}

\begin{abstract}
${ }^{1}$ Department of Oncology, Cancer Research Institute, Slovak Academy of Sciences, Vlárska 7, 83391 Bratislava, Slovak Republic; ${ }^{2}$ Laboratory of Oncovirology, Cancer Research Institute, Siberian Branch of the Russian Academy of Medical Sciences, Tomsk, Kooperativnii str. 5, 634050 Tomsk, Russian Federation ${ }^{3}$ Tomsk State University, Tomsk, Lenina avenue 36, 634050 Tomsk, Russian Federation; ${ }^{4}$ Department of Pediatric Haematology and Oncology, Faculty of Medicine and Pediatric Faculty Hospital, Limbová 1, 83340 Bratislava, Slovak Republic; ${ }^{5}$ Department of Clinical Oncology, National Cancer Institute, Klenová 1, 83310 Bratislava, Slovak Republic
\end{abstract}

${ }^{*}$ Correspondence: Igor.Beliaev@savba.sk

Received May 20, 2014 / Accepted July 23, 2014

\begin{abstract}
The precise diagnosis of acute lymphoblastic leukemia is essential for correct prognosis assessment and therapy regimen selection. At present, immunophenotyping, cytogenetics and molecular screening are major and complementary methods utilized in a routine leukemia diagnostics. The aim of this study was to validate the application of multiplex reverse transcription-polymerase chain reaction (RT-PCR) assay for molecular diagnosis of the most common pediatric acute lymphoblastic leukemia-associated fusion transcripts. Our data show that screening of bone marrow and/or peripheral blood by RT-PCR, consisting of multiplex and monoplex PCR, confirmed results of real-time quantitative PCR (RT qPCR). This screening may provide a reliable, specific and sensitive method amenable to standard laboratory practice and a cost-effective alternative to more complex and expensive RT qPCR techniques.
\end{abstract}

Key words: acute leukemia, preleukemic gene fusions, reverse transcription-PCR, leukemia diagnosis

Chromosomal translocations resulting into gene fusions are often initiating events in leukemogenesis, arising in most cases of childhood leukemia prenatally in hematopoietic stem cells (HSC) or progenitor cells (PC) and constituting covert preleukemic gene fusions (PGF) [1]. These genetic changes are usually not sufficient to cause overt leukemia and secondary, usually postnatal genetic hits are required. The cumulative risk of any child to develop leukemia before the age of 15 years is around 1 in 2,000. The main type of childhood leukemia - acute lymphoblastic leukemia (ALL) - has a five-fold higher incidence than acute myeloblastic leukemia (AML). The most common chromosomal translocations and resulting gene fusions associated with ALL are shown in Table 1 [2].

In-frame chimeric genes, generating fusion proteins with altered properties are hallmark of leukemia [3,4]. The total number of genes found to be involved in translocations causing childhood leukemia is growing [5]. However, many of them are rare and certain genes predominate, e.g. TEL, $M L L, A M L 1$, $B C R, A B L 1, E T O$. It is not surprising that the same genes are crucial for the normal function of HSC, as shown by knockout experiments in mice [6-8].

The identification and characterization of chromosomal translocations in leukemia has had important clinical implications. The translocations themselves define molecular subtypes of disease and provide independent prognostic markers that influence choice of therapy $[9,10]$. In addition, these unique, specific and stable markers can also be used to track the response to therapy [11].

Currently, conventional cytogenetic analysis, molecular-based technologies and immunophenotyping are complementary tests for accurate diagnosis of acute leukemia. However, cryptic (submicroscopic) translocations cannot be discerned by cytogenetic approach resulting in $>1 \%$ to $<35 \%$ frequency of false-negative cytogenetic analyses. It has been demonstrated that cytogenetics failed to detect the most common $\mathrm{t}(12 ; 21)$ translocation in $26 \%$ of B-ALL cases, in which the TEL-AML1 (ETV6-RUNX1) fusion transcripts could be detected by reverse transcription-polymerase chain 
reaction (RT-PCR) [12]. It is extremely important to identify these recurrent chromosomal translocations rapidly and efficiently, therefore molecular screening methods have assumed an increasing role in the initial evaluation of most, if not all, leukemic patients. It is clear, however, that PCR methodologies cannot fully replace karyotypic analyses, for at least two reasons: (i) numerical aberrations and abnormalities other than balanced translocations cannot be detected, and (ii) unknown balanced translocations are obviously not detected.

The molecular PCR-based screening methods consist in detection and/or quantification of common leukemia specific chimeric transcripts resulting from corresponding chromosomal translocations. Basically, these methods can be divided into two major groups: (i) standard qualitative reverse transcription-PCR (RT-PCR) and (ii) real-time quantitative PCR (RT qPCR). Both these methodological approaches rely on quality and efficiency of RNA extraction from patient's BM or $\mathrm{PB}$, and subsequently on efficiency of reverse transcription since detection of fusion transcripts is accomplished through examination of corresponding cDNA by PCR. There are several pros and cons in using these screening methods in leukemia diagnostics. Real-time amplification assays have several advantages: they allow a more precise quantification and achieve higher sensitivity level $\left(10^{-4}\right.$ to $\left.10^{-5}\right)$ in comparison to standard RT-PCR [13]. In addition, the real-time system obviates post-PCR manipulations, thus preventing carry-over contaminations, which is critical in clinical settings. It might be argued that the standard multiplex system is weakened by decrease in sensitivity relative to monoplex PCR reactions $\left(10^{-2}\right.$ to $\left.10^{-3}\right)$ [2]. However, in acute lymphoblastic leukemia at diagnosis, the cell source used for RNA preparations is usually greater than $70 \%$ of leukemic blasts suggesting that the sensitivity of multiplex assays greatly exceeds threshold for a reliable and accurate detection of positive samples. It would be extremely labor intensive and rather expensive to evaluate leukemias via a panel of individual monoplex assays. This is circumvented by the use of multiplex RT-PCR assays. From a large number of such assays which have been described, we have chosen the multiplex RT-PCR designed by Pakakasama and colleagues [14] because it uses standardized PCR primers [2]. We used this assay to analyze a set of 10 samples of pediatric ALL patients or healthy donors (BM and/or PB). Our data show that an assay consisting of combined multiplex and monoplex PCR represents a reliable, sensitive and cost-effective alternative to commonly used RT qPCR for diagnostic analysis of patient's samples for the presence of most common well-defined chromosomal aberrations associated with fusion gene transcripts frequently occurring in ALL (see Table 1).

\section{Patients and methods}

Patients. Group of ALL patients consisted of two boys and three girls (Table 4). Mean age in the group was $60 \pm 24$ months (from 24 to 83 months). One patient was with an unknown aberration, not included in Panel A translocations, three patients were with E2A-PBX1 and one patient with BCR-ABL (p190) fusion gene. Patients were treated in the Department of Pediatric Hematology and Oncology in Bratislava. This study was approved by the local ethics committee, children's parents gave written informed consent to participate in the study.

Diagnostic tools. Diagnosis was based on the FrenchAmerican-British classification and flow cytometric immunophenotyping using a standard set of monoclonal antibodies according to the European Group for Immunological Characterization of Leukemia [15]. FISH and immunophenotyping were routinely performed on samples from each patient. Pathological cells constituted from $72 \%$ to $99 \%$.

Healthy controls. Healthy controls group included five children (one boy and four girls) with mean age $72 \pm 64$ months (from 17 to 164 months).

RNA samples. Bone marrow (BM) aspirates and/or peripheral blood (PB) samples were collected at the time of routine diagnostic procedure after written informed consent was obtained from the patient's guardians. In majority of cases, BM or PB was drawn directly into TEMPUS ${ }^{\mathrm{rm}}$ Blood RNA tube (Applied Biosystems, Foster City, California, USA) and total RNA was purified following standard protocol. Alternatively, lymphocytes and monocytes were separated from $1-3 \mathrm{ml}$ of BM/PB by the standard gradient centrifugation using Ficollbased LSM 1077 solution (PAA Laboratories GmbH, Austria). Subsequently, total RNA was extracted from freshly isolated cells with TRIzol (Invitrogen, Carlsbad, California, USA) at the National Cancer Institute or with RNAzol (Research Molecular Center, Ohio, USA) in our laboratory using standard protocol

Table 1. ALL-associated chromosomal translocations and corresponding PGFs

\begin{tabular}{lcccc}
\hline $\begin{array}{l}\text { Panel A } \\
\text { Translocation }\end{array}$ & PGF & $\begin{array}{c}\text { FT** size (bp) } \\
{[\text { variant (bp)] }}\end{array}$ & Incidence in children & Prognosis \\
\hline $\mathrm{t}(12 ; 21)(\mathrm{p} 13 ; \mathrm{q} 22)$ & $\begin{array}{c}\text { TEL-AML1 } \\
(E T V 6-R U N X 1)\end{array}$ & $298[259]$ & $25 \%$ & overall good \\
$\mathrm{t}(1 ; 19)(\mathrm{q} 23 ; \mathrm{p} 13)$ & $E 2 A-P B X 1$ & $373[400]$ & $3-5 \%$ & high-risk symptoms \\
$\mathrm{t}(9 ; 22)(\mathrm{q} 34 ; \mathrm{q} 11)$ & $B C R-A B L(\mathrm{p} 190)$ & $521[347]$ & $5 \%$ & poor \\
$\mathrm{t}(4 ; 11)(\mathrm{q} 21 ; \mathrm{q} 23)$ & $M L L-A F 4$ & $184-673$ & $5 \%$ & poor \\
\hline
\end{tabular}

Notes: ${ }^{*} \mathrm{PGF}-$ preleukemic gene fusion, ${ }^{* *} \mathrm{FT}-$ fusion transcript 


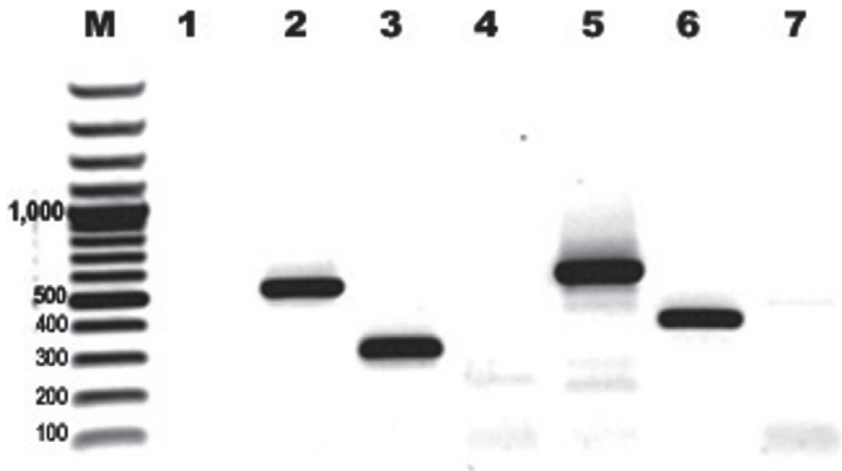

Figure 1. Panel A multiplex RT PCR analysis. M - molecular weight marker (size shown in bps), 1 to 6 - $1 \mu$ l of cDNA from ALL-positive patients, 1 - BCR$A B L(\mathrm{p} 210)^{+}, 2-B C R-A B L(\mathrm{p} 190)^{+}, 3-T E L-A M L 1^{+}, 4-S I L-T A L^{+}, 5-M L L-$ $A F 4^{+}, 6$ - E2A-PBX1+, 7 - negative control (no cDNA added).

recommended by manufacturer. The concentration and purity of isolated RNA was measured by Nanodrop N-1000 instrument (Thermo Scientific, Delaware, USA). The integrity of RNAs was determined by running samples on $1.5 \%$ denaturing agarose gel and visual assessment of intensity of $28 \mathrm{~S}$ and $18 \mathrm{~S}$ rRNA bands. RNA was stored at $-80^{\circ} \mathrm{C}$.

cDNA, RT PCR, and Panel A. cDNA used as a template in the RT-PCR, was reverse transcribed in $20-\mu \mathrm{l}$ reaction from $1 \mu \mathrm{g}$ of total RNA using $1 \mathrm{mM}$ dNTP mix, random hexamer and oligo(dT) 18 primer $5 \mu \mathrm{M}$ each, $20 \mathrm{U}$ RNAse inhibitor and $200 \mathrm{U}$ RevertAid H- Reverse Transcriptase following manufacturer's protocol (Thermo Scientific, St. Leon-Rot, Germany). The reverse transcription of cDNA used in RT qPCR was performed identically, except that only random hexamer primers at final concentration of $5 \mu \mathrm{M}$ were used. Briefly, reaction mixture containing all components except reverse transcriptase was incubated at $25^{\circ} \mathrm{C}$ for $5 \mathrm{~min}$, and after addition of the enzyme one cycle of $25^{\circ} \mathrm{C}$ for $10 \mathrm{~min}, 42^{\circ} \mathrm{C}$ for $60 \mathrm{~min}$, and $70^{\circ} \mathrm{C}$ for $10 \mathrm{~min}$ was performed. cDNA was stored at $-20^{\circ} \mathrm{C}$. The suitability of RNA for subsequent PCR screening was estimated by PCR amplification of corresponding cDNA using 18S rRNA gene specific primers as described previously $[2,14]$.

We used multiplex RT-PCR designed by Pakakasama and colleagues [14], in which the common fusion transcripts as-

Table 2. Total RNA from ALL-positive patients

\begin{tabular}{ccccc}
\hline No. Source & $\begin{array}{c}\text { RNA concentration } \\
{[\mathrm{ng} / \mu \mathrm{l}]}\end{array}$ & $\begin{array}{c}\text { RNA purity } \\
{[260 / 280]}\end{array}$ & Positivity \\
\hline 1 & BM & $1,685.4$ & 2.03 & $B C R-A B L(\mathrm{p} 210)$ \\
2 & BM & 910.5 & 1.86 & $B C R-A B L(\mathrm{p} 190)$ \\
3 & BM & 379.3 & 1.85 & TEL-AML1 \\
4 & BM & $1,287.4$ & 1.95 & SIL-TAL \\
5 & BM & 864.2 & 1.72 & MLL-AF4 \\
6 & PB & $1,986.5$ & 1.88 & E2A-PBX \\
\hline
\end{tabular}

sociated with acute childhood leukemia were divided into two panels. Panel A was assigned to B-lineage ALL associated fusion genes: TEL-AML1, E2A-PBX1, BCR-ABL (p190), and MLL-AF4, whereas panel $\mathrm{B}$ was designated to detect fusion genes associated with AML. All primers were designed according to Van Dongen and colleagues [2] and synthesized by Integrated DNA Technologies (IDT Inc., Coralville, Iowa, USA). The multiplex PCR was carried out in a final volume of $25 \mu \mathrm{l}$ with $1 \mu \mathrm{l} \mathrm{cDNA}$, 1x Dream Taq PCR buffer containing $2 \mathrm{mM} \mathrm{MgCl}_{2}, 200 \mu \mathrm{M}$ dNTP's, $120 \mathrm{nM}$ of each primer pair and $0.625 \mathrm{U}$ Dream Taq DNA polymerase (Thermo Scientific, St. Leon-Rot, Germany). The PCR cycling parameters were as follows: initial denaturation step at $94^{\circ} \mathrm{C}$ for $3 \mathrm{~min}$, the 35 cycles of $94^{\circ} \mathrm{C}$ for $45 \mathrm{~s}, 63^{\circ} \mathrm{C}$ for $1 \mathrm{~min}$, and $72^{\circ} \mathrm{C}$ for $1.5 \mathrm{~min}$, the final extension executed at $72^{\circ} \mathrm{C}$ for $10 \mathrm{~min}$. The negative control without $\mathrm{cDNA}$ was included for each PCR run. A 15- $\mu$ l aliquot of multiplex PCR (total reaction volume of $25 \mu \mathrm{l}$ ) was visualized on $1 \%$ agarose gel stained with GoldView $^{\mathrm{Tm}}$ (SBS Genetech, Beijing, China) in 0.5x TBE running buffer. The multiplex/monoplex PCR analysis was performed in single reactions.

Real-time quantitative PCR. Routine RT qPCR was performed for most frequent ALL translocations, including TEL-AML1, E2A-PBX1, BCR-ABL (p190), BCR-ABL p(210), SIL-TAL, and MLL-AF4. The suitability of RNA for PCR screening was estimated by RT qPCR amplification of corresponding $\mathrm{cDNA}$ using $\mathrm{c}-\mathrm{ABL}$ control gene specific primers as described previously [13].

The RT qPCR contained $4 \mu \mathrm{l}$ cDNA (100ng RNA equivalent), 300nM each primer, 200nM probe (5'-fluorophore was FAM, 3'-quencher was TAMRA; synthesized by Merck), and TaqMan universal PCR master mix from Applied Biosystems. The primers and probes were synthesized by VBC-Biotech (Wien, Austria) and designed according to Gabert and colleagues [13]. The plasmid standards with individual fusion genes subcloned into PCR II TOPO vector were from Qiagen (Marseille, France). The RT qPCRs were performed on RotorGene 3000 instrument following the protocol by Gabert and colleagues [13]. Each sample was analyzed in duplicates. Samples were regarded as positive for a particular rearrangement if a fusion transcript was present in at least one reaction.

\section{Results}

Any PCR-based assay used routinely in diagnostics must meet essential criteria, including reliability, specificity and accuracy. In order to verify whether our multiplex PCR method fulfills these parameters, total RNAs isolated from leukemic patients and tested positive for panel A (B-ALL) fusion transcripts during routine RT-qPCR analysis by a certified laboratory (National Cancer Institute, Bratislava, Slovakia) was examined. Table 2 shows source of RNA, total RNA concentration and purity, and positivity for specific gene fusions.

One $\mu \mathrm{g}$ of total RNA isolated from $\mathrm{BM}$ or $\mathrm{PB}$ was reverse transcribed and subsequently $1 \mu \mathrm{l}$ of $\mathrm{cDNA}(1 / 20)$ was used for panel A multiplex PCR analysis (Figure 1). Samples tested 
positive for two fusion transcripts, $B C R-A B L(\mathrm{p} 210)$ and SIL$T A L$, which are not present in panel $A$ and a negative control without cDNA, were also included in the assay. Data show that all four positive samples included in panel A (lanes 2, 3, 5 , and 6) were confirmed by multiplex PCR and the PCR fragments of expected size were robust and specific. In addition, the two fusion transcripts not included in panel $\mathrm{A}$ as well as negative control (no cDNA) were tested negative (lanes 1, 4, and 7 , respectively). These data suggest that the sensitivity and specificity of panel A multiplex PCR may be sufficient for accurate diagnosis of four most common fusion transcripts associated with ALL.

However, the specificity of the assay is affected by the existence of various types of MLL-AF4 fusion transcripts, reflecting the site of breakpoint between $M L L$ and AF4 genes within $\mathrm{t}(4 ; 11)$ translocation. Thus, the size of RT-PCR products for MLL-AF4 is within a relatively broad range between 184 and $673 \mathrm{bp}$, depending on number of exons from the two genes present in particular fusion transcript as shows Table 3 (the PCR product sizes were taken from [13]).

Our data show that using panel A multiplex PCR allowed us unambiguously to determine the type of fusion gene in patient's samples, since the size of corresponding PCR product was clearly distinguishable for each fusion transcript, i.e 298 bp for TEL-AML1, $373 \mathrm{bp}$ for E2A-PBX1, $521 \mathrm{bp}$ for BCR-ABL (p190), and $559 \mathrm{bp}$ for $M L L-A F 4$. However, the sizes of several PCR products associated with MLL-AF4 are quite close to those typical for $E 2 A-P B X 1$ or $B C R-A B L$ (p190), therefore we suggest a modification of original multiplex PCR which will be described in Discussion.

Next, we examined 10 samples, either from pediatric patients or healthy donors, for the presence of most common fusion transcripts (TEL-AML1, E2A-PBX1, BCR-ABL (p190), and $M L L-A F 4$ ) in their bone marrow and/or peripheral blood. The results of the screening are summarized in Table 4, including the method of RNA isolation, concentration and purity of isolated total RNA, and results of multiplex/monoplex

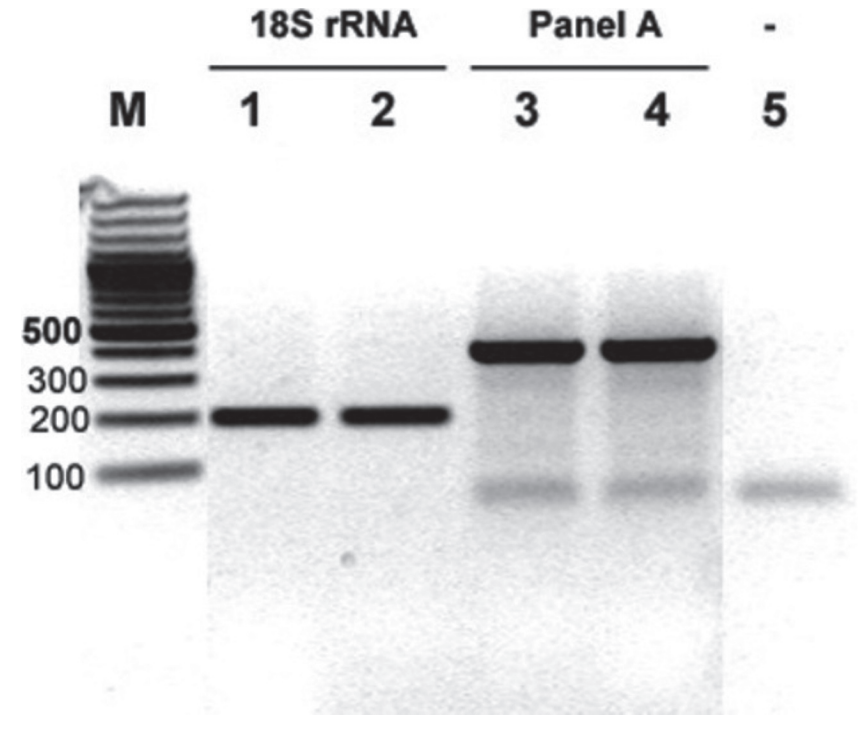

Figure 2. Panel A multiplex PCR analysis of patient \#3. M - molecular weight marker, 1, 2 - $18 S$ rRNA gene (BM, PB), 3, 4 - Panel A (BM, PB), 5 - negative control (no cDNA).

PCR analysis. Importantly, our findings are in a full agreement with results accomplished during routine diagnostics by a certified laboratory that uses RT qPCR technique in a monoplex format.

As an example we show the results of multiplex PCR analysis of patient \#3 (Figs. 2-4). Total RNA was isolated from $\sim 1 \mathrm{ml}$ of each BM and $\mathrm{PB}$ using TEMPUS ${ }^{*}$ method, yielding $160 \mathrm{ng} / \mu \mathrm{l}\left(\mathrm{OD}_{260 / 280}=2.07\right)$ and $664 \mathrm{ng} / \mu \mathrm{l}\left(\mathrm{OD}_{260 / 280}=2.16\right)$, respectively. The integrity of $\mathrm{cDNA}$ was estimated using level of amplification of $18 \mathrm{~S}$ rRNA control gene. The agarose gel electrophoresis of relevant PCR products ( 200bp) revealed a marked cDNA integrity (Figure 2, lanes 1 and 2 ) suggesting that isolated total RNA or more precisely its reverse tran-

Table 3. Size of PCR products - standard (variants) and their frequency in pediatric ALL patients.

\begin{tabular}{|c|c|c|c|}
\hline Fusion gene & $\begin{array}{c}\mathbf{A} \leftrightarrow \mathbf{B}^{\star} \\
\text { Major PCR product } \\
\text { (variant) [bp] }\end{array}$ & $\begin{array}{c}\mathbf{C} \leftrightarrow \mathbf{D}^{\star *} \\
\text { Major PCR product } \\
\text { (variant) }[\mathrm{bp}]\end{array}$ & $\begin{array}{c}\text { Frequency in PGF } \\
\text { positive children [\%] }\end{array}$ \\
\hline$T E L-A M L 1$ & 298 (259) & $181(142)$ & $\sim 100 \%$ \\
\hline$E 2 A-P B X 1$ & $373(400)$ & $289(316)$ & $\sim 100 \%$ \\
\hline$B C R-A B L(\mathrm{p} 190)$ & $521(347)$ & $381(207)$ & $\sim 100 \%$ \\
\hline \multirow[t]{9}{*}{$M L L-A F 4$} & (184) & (127) & rare \\
\hline & (353) & (296) & $<5 \%$ \\
\hline & 382 & 325 & $16 \%$ \\
\hline & 427 & 370 & $<30 \%$ \\
\hline & (514) & (457) & $<5 \%$ \\
\hline & 559 & 502 & $39 \%$ \\
\hline & (541) & (484) & $<5 \%$ \\
\hline & (628) & (571) & rare \\
\hline & (673) & (616) & $<5 \%$ \\
\hline
\end{tabular}

* external primers; ${ }^{* *}$ - internal primers 


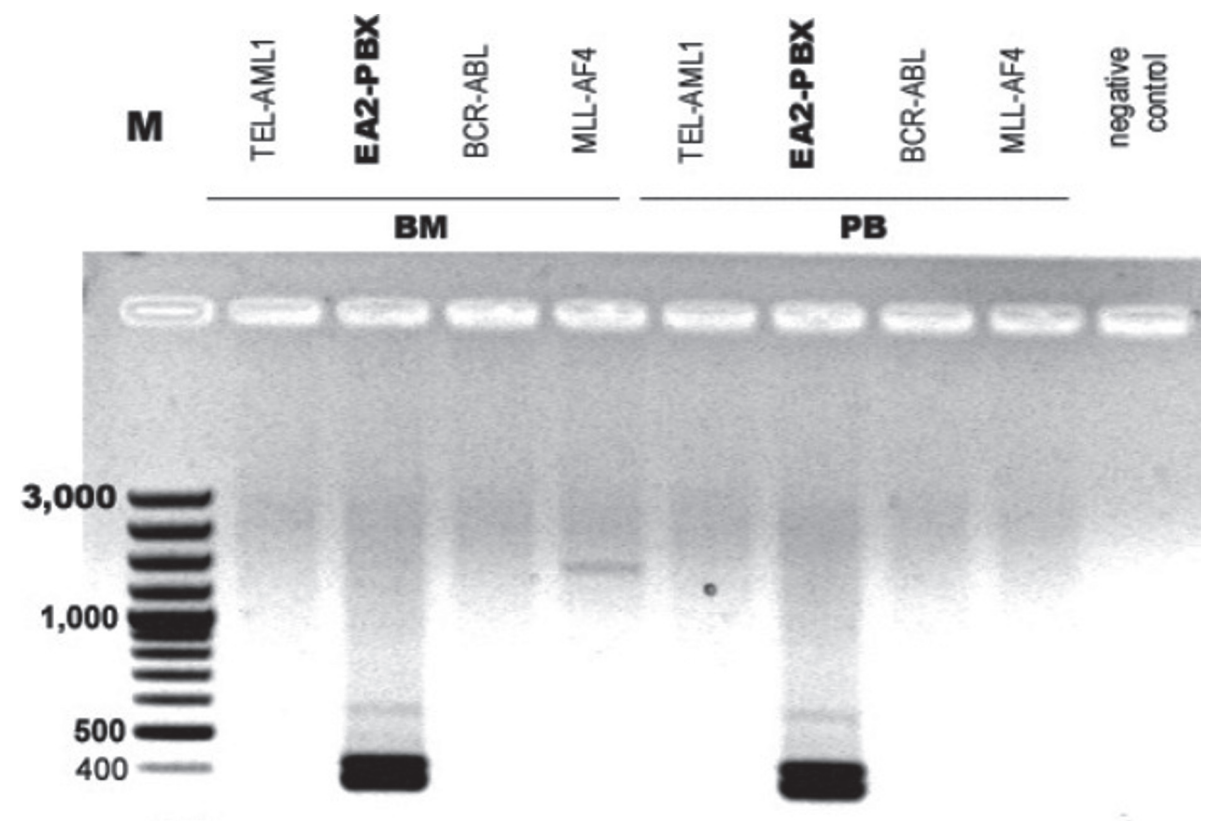

Figure 3. Panel A monoplex PCR analysis of patient \#3. M - molecular weight marker, negative control - no cDNA

scribed cDNA is suitable for subsequent analyses by PCR methods. The multiplex PCR analysis of patient \#3's both $\mathrm{BM}$ (lane 3) and $\mathrm{PB}$ (lane 4) samples showed a clear positivity in panel A. The panel A positive PCR fragment is $\sim 400 \mathrm{bp}$ suggesting most probably positivity for $E 2 A-P B X 1$ gene fusion. However, due to a broader size range of $M L L-A F 4^{+}$PCR products, the positivity for $M L L-A F 4$ gene fusion cannot be absolutely excluded. To test our presumption, monoplex
PCRs for individual gene fusions included in Panel A array was performed (Figure 3), although negativity of TEL-AML1 as well as BCR-ABL1 (p190) due to easily discernible PCR fragment sizes was expected.

The monoplex PCR analysis of patient \#3's samples confirmed our presumption that both $\mathrm{BM}$ and $\mathrm{PB}$ were tested positive for $E 2 A-P B X 1$ gene fusion. The thickness of the band corresponding to $E 2 A-P B X 1$ PCR product from both cell

Table 4. RNA samples from ALL patients and healthy donors (HD) analyzed by Panel A

\begin{tabular}{|c|c|c|c|c|c|c|}
\hline $\begin{array}{l}\text { Proband } \\
\text { No./code }\end{array}$ & $\begin{array}{l}\text { Cell source/ } \\
\text { volume }\end{array}$ & $\begin{array}{l}\text { RNA isolation } \\
\text { method }\end{array}$ & $\begin{array}{l}\text { Total RNA concentration } \\
{[\mathrm{ng} / \mu \mathrm{l}]}\end{array}$ & $\begin{array}{l}\text { RNA purity } \\
\left(\mathrm{OD}_{260 / 280}\right)\end{array}$ & $\begin{array}{l}\text { cDNA } \\
\text { integrity }\end{array}$ & $\begin{array}{c}\text { FT } \\
\text { positivity }\end{array}$ \\
\hline 1 ALL/PL1 & $\mathrm{BM} / 5 \mathrm{ml}$ & RNAzol & 256 & 2.02 & ++ & negative \\
\hline $2 \mathrm{HD} / \mathrm{PL} 2$ & $\mathrm{BM} / 3 \mathrm{ml}$ & TEMPUS & 610 & 2.08 & +++ & negative \\
\hline 3 ALL/PL3 & $\begin{array}{l}\mathrm{BM} / 2.5 \mathrm{ml} \\
\mathrm{PB} / 2.5 \mathrm{ml}\end{array}$ & $\begin{array}{l}\text { TEMPUS } \\
\text { TEMPUS }\end{array}$ & $\begin{array}{c}1,163 \\
374\end{array}$ & $\begin{array}{l}2.18 \\
2.11\end{array}$ & $\begin{array}{l}+++ \\
+++\end{array}$ & $\begin{array}{l}E 2 A-P B X 1 \\
E 2 A-P B X 1\end{array}$ \\
\hline 4 ALL/PL4 & $\begin{array}{l}\mathrm{BM} / 1 \mathrm{ml} \\
\mathrm{PB} / 1 \mathrm{ml}\end{array}$ & $\begin{array}{l}\text { TEMPUS } \\
\text { TEMPUS }\end{array}$ & $\begin{array}{l}160 \\
664\end{array}$ & $\begin{array}{l}2.07 \\
2.16\end{array}$ & $\begin{array}{l}+++ \\
+++\end{array}$ & $\begin{array}{l}E 2 A-P B X 1 \\
E 2 A-P B X 1\end{array}$ \\
\hline 5 HD/PL5 & $\mathrm{BM} / 1.5 \mathrm{ml}$ & TEMPUS & 150 & 2.05 & +++ & negative \\
\hline 6 ALL/PL6 & $\begin{array}{c}\mathrm{BM} / 1.5 \mathrm{ml} \\
\mathrm{PB} / 2.5 \mathrm{ml} \\
\mathrm{CD} 34^{+}\end{array}$ & $\begin{array}{l}\text { RNAzol } \\
\text { RNAzol } \\
\text { RNAzol }\end{array}$ & $\begin{array}{l}230 \\
409 \\
200\end{array}$ & $\begin{array}{l}1.97 \\
1.98 \\
1.96\end{array}$ & $\begin{array}{l}+++ \\
+++ \\
+++\end{array}$ & $\begin{array}{l}B C R-A B L \\
B C R-A B L \\
B C R-A B L\end{array}$ \\
\hline 7 ALL/PL7 & $\mathrm{PB} / 3 \mathrm{ml}$ & TEMPUS & 6 & 1.15 & + & $E 2 A-P B X 1$ \\
\hline $8 \mathrm{HD} / \mathrm{PL} 8$ & $\mathrm{BM} / 2 \mathrm{ml}$ & TEMPUS & 636 & 2.12 & +++ & negative \\
\hline 9 HD/PL12 & $\begin{array}{l}\mathrm{BM} / 3 \mathrm{ml} \\
\mathrm{PB} / 3 \mathrm{ml}\end{array}$ & $\begin{array}{l}\text { TEMPUS } \\
\text { TEMPUS }\end{array}$ & $\begin{array}{l}1,733 \\
1,120\end{array}$ & $\begin{array}{l}2.14 \\
1.76\end{array}$ & $\begin{array}{l}+++ \\
+++\end{array}$ & $\begin{array}{l}\text { negative } \\
\text { negative }\end{array}$ \\
\hline 10 HD/PL17 & $\mathrm{BM} / 2 \mathrm{ml}$ & TEMPUS & 452 & 2.01 & +++ & negative \\
\hline
\end{tabular}

Notes: ${ }^{*}$ Patient \#PL1 was negative on all rearrangements analyzed by routine RT qPCR and by Panel A. cDNA integrity was assessed by the intensity of the $18 \mathrm{~S}$ rRNA gene, classified in 3 levels from low to high $(+,++,+++)$ 


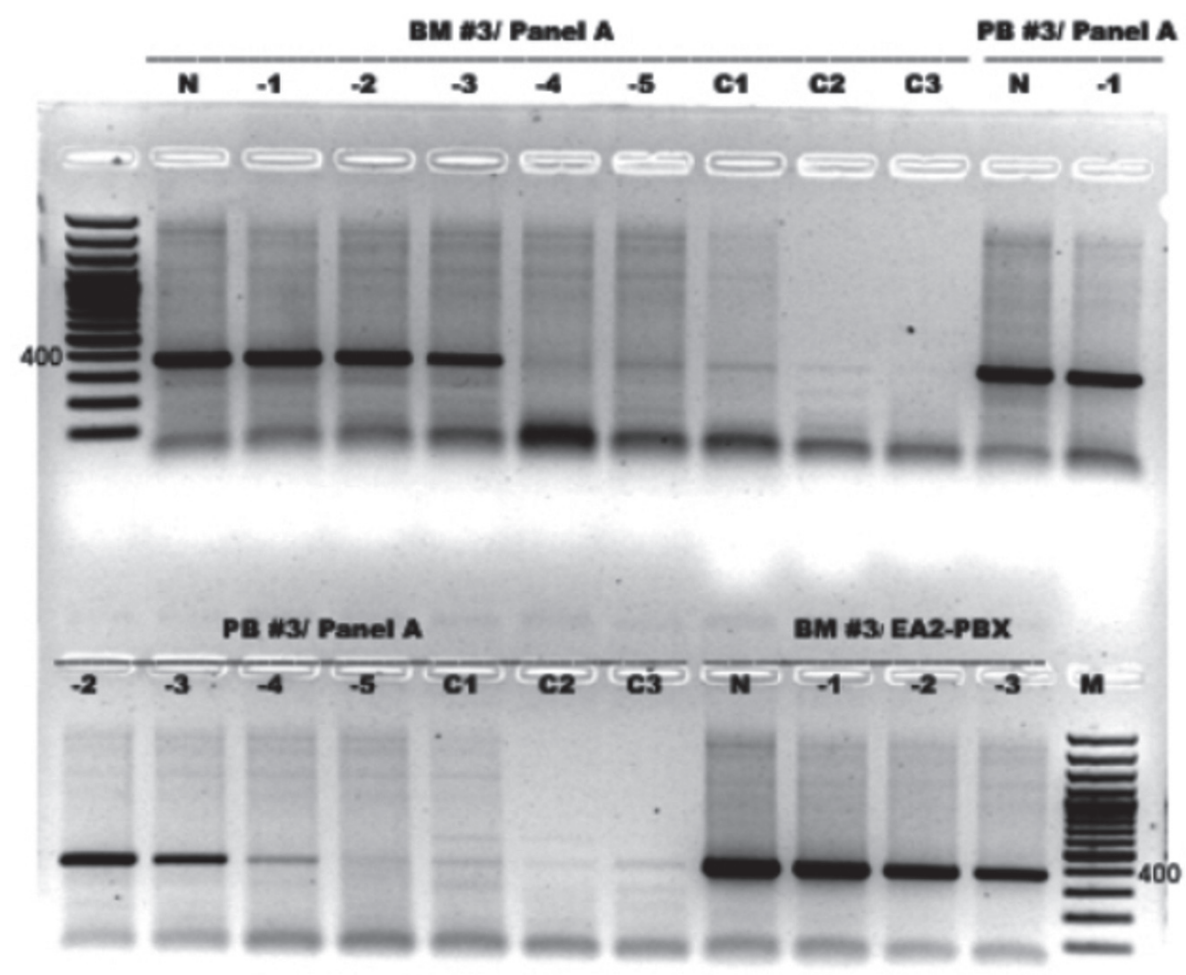

Figure 4. Sensitivity of Panel A multiplex PCR. M - molecular weight marker (indicating a 400bp fragment), BM (PB) \#3/ Panel A (E2A/PBX1) - bone marrow (peripheral blood) from patient \#3 examined by Panel A multiplex PCR (monoplex PCR for E2A/PBX1), -1 to -6 - decimal dilutions of undiluted (N) cDNA, C1-3 - negative controls (no cDNA).

sources is comparable, suggesting that both $\mathrm{BM}$ and $\mathrm{PB}$ may contain similar level of positive blasts at initial diagnosis of this patient.

In summary, multiplex and monoplex PCR analysis of patient \#3's BM and PB showed a high specificity of the screening method. Next, we wished to investigate the sensitivity level of the multiplex PCR assay using decimal dilutions of cDNA reverse transcribed from patient \#3's total RNA (Figure 4). The data show that cDNA dilutions up to $10^{-3}$ in case of $\mathrm{BM}$ and even up to $10^{-4}$ for $\mathrm{PB}$ are sufficient for a successful detection of relevant fusion transcript in patient's sample.

\section{Discussion}

Due to a high variability in size of PCR products specific for MLL-AF4 gene fusions, we suggest to divide the analysis of panel A translocations in two reactions: (1) multiplex PCR for TEL-AML1, E2A-PBX1 and BCR-ABL (p190), and (2) monoplex PCR for $M L L-A F 4$ gene fusions. In this way, using two PCR reactions will allow an unambiguous determination of the four translocations belonging to panel $\mathrm{A}$. We also suggest the primer pair specific for $18 S$ rRNA control gene to be included in MLL-AF4 monoplex PCR for checking the integrity of template cDNA. Thus, combined multiplex/monoplex PCR would give an answer about positivity and specificity for B-ALL.
Our data suggest that a standard reverse transcriptionpolymerase chain reaction (RT-PCR) consisting of multiplex and monoplex RT-PCR may provide a reliable, sensitive and accurate molecular PCR-based method for detection of most common gene fusion transcripts associated with B-ALL in children. However, due to relatively low number of samples examined in this study, we cannot make any general conclusions and recommendations for a routine application. Even if we take into account relatively high average number of positive blasts in BM of B-ALL pediatric patients at diagnosis and the sensitivity of our screening method (Fig. 4, approx. $10^{-3}$ ) we do not suggest standardized RT qPCR to be replaced by multiplex/monoplex PCR. However, after testing of sufficient amount of clinal samples, our standard multiplex/monoplex RT PCR might be considered as a cost-effective and less complex alterantive method for detection of most frequent gene fusions associated with acute B-ALL in children. In addition, our technique would have to be supplemented with less frequent fusion transcripts as proposed by European Hematology Association.

Upon comparison, the two principal approaches have several advantages as well as shortcomings. In general, standard RT-PCR methods have significantly lower sensitivity than real-time qPCR, however, it is very common that at diagnosis of acute leukemia a very high proportion of blasts, especially 
in $\mathrm{BM}$ contain the corresponding fusion gene transcript. It means that in such cases theoretically a method with at least $10^{-1}$ sensitivity would be sufficient for a successful detection of positive clones. The sensitivity of multiplex RT-PCR we used in this study was estimated to be approx. $5 \times 10^{-3}$ using standard plasmids with cloned gene fusions in pCR II TOPO vector as template [16]. The real sensitivity of our multiplex RT-PCR might be slightly lower because our sensitivity test assay did not take into consideration the efficiency of cDNA synthesis which is integral part of the RT-PCR method. However, our results obtained on patient's samples, both $\mathrm{BM}$ and/or PB, show that the minimal dilutions of $10^{-3}$ of cDNA result in an unambiguous detection of positivity (Figure 4), indicating that the copy number of detected fusion transcripts in positive samples is at least two orders of magnitude above the threshold of the screening method. We have not estimated the sensitivity of monoplex RT-PCRs which is expected to reach at least the sensitivity of multiplex RT-PCR. The sensitivity of RT qPCR is significantly higher, reaching in our laboratory maximum level of $\sim 1-3 \times 10^{-5}[16]$ which may be considered as too high providing no benefit for primary diagnostics. Extremely high sensitivity of RT qPCR can be utilized for monitoring of minimal residual disease during leukemic patient's treatment. There might be a higher risk of cross-contamination in standard RTPCR methods, especially in nested PCR where the template is a PCR product. However, our data suggest that nested PCR might be rarely needed, if at all, since multiplex and monoplex PCRs are sufficient for an accurate detection of gene fusion transcripts included within panel A. Therefore, mostly only multi/monoplex PCRs will be used, and in this case the risk of contamination in both standard and real-time PCRs is likely to be similar. Both compared methods can be performed in a single PCR run. However, quantitation during real-time PCR is based on the utilization of plasmid standards with cloned gene fusions which might produce a source of sample contamination, especially when a higher amounts of samples are being analyzed. Taking these possible risks for contamination into consideration, we might assume a similar level of cross-contamination between standard RTPCR and real-time qPCR. When comparing the specificity of both assays, obviously RT qPCR reaches a higher level of specificity due to the usage of not only equally specific primers as in standard RT-PCR, but in addition also a specific fluorescent-labeled probe, allowing for precise quantification of fusion transcripts. This advantage, however, is not relevant for diagnosis, i.e. in cases where usually a very high proportion of blasts are positive.

However, there is a considerable difference in total expenses between the two methods. In our calculations, we excluded costs for the steps that are identical for both methods, including isolation of total RNA and its reverse transcription into cDNA and also the expenses for PCR instrument (difference is about $€ 25,000$ ). In case of standard PCR, however, we had to include the costs for agarose gel electrophoresis, i.e. agarose, running buffer, DNA visualization stain). Taking into consideration the consumption of all chemicals and enzymes, the total expenses for a single patient analysis were approximately $€ 1.3$ and $€ 13.0$ for standard RT-PCR and RT qPCR, respectively. Another important parameter is the time required for the analysis. The total time required for completion of each procedure is likely to be very similar, slightly longer for standard PCR at $\sim 3.5 \mathrm{~h}$ per assay, including both multiplex a monoplex PCRs, gel electrophoresis of corresponding PCR products and their UV-visualization), and $\sim 3 \mathrm{~h}$ per assay for RT $\mathrm{qPCR}$ analysis which comprises reaction mixture preparation, PCR running, and results analysis.

This study evaluated the most common fusion transcripts associated with ALL. However, molecular analysis in routine diagnosis must be carried out strictly according to the recommended standard procedures issued by EHA (European Hematology Association). Therefore, suggested approach would have to be supplemented with those less frequent fusion transcripts before it can be recommended to replace reliable but more expensive RT qPCR assay.

Acknowledgements: This study was supported by the Slovak Research and Development Agency (APVV 0669-10); the National Scholarship Program of the Slovak Republic (SAIA); the Joint Research Project "Cancer diagnostics and assessment of cancer risks" between Slovak Academy of Sciences (SAS) and Russian Academy of Medical Sciences (RAMS), and the VEGA Grant Agency (2/0150/11) of the Slovak Republic.

\section{References}

[1] GREAVES MF, WIEMELS J Origins of chromosome translocations in childhood leukaemia. Nature reviews. Cancer 2003; 3: 639-649. http://dx.doi.org/10.1038/nrc1164

[2] VAN DONGEN JJ, MACINTYRE EA, GABERT JA, DELABESSE E, ROSSI V et al. Standardized RT-PCR analysis of fusion gene transcripts from chromosome aberrations in acute leukemia for detection of minimal residual disease. Report of the BIOMED-1 Concerted Action: investigation of minimal residual disease in acute leukemia. Leukemia 1999; 13: 1901-1928. http://dx.doi.org/10.1038/sj.leu.2401592

[3] LOOK AT Oncogenic transcription factors in the human acute leukemias. Science (New York, N.Y 1997; 278: 1059-1064.

[4] ROWLEY JD The critical role of chromosome translocations in human leukemias. Annual review of genetics 1998; 32: 495-519. http://dx.doi.org/10.1146/annurev. genet.32.1.495

[5] MEYER C, HOFMANN J, BURMEISTER T, GROGER D, PARK TS et al. The MLL recombinome of acute leukemias in 2013. Leukemia 2013; 27: 2165-2176. http://dx.doi.org/ 10.1038/leu.2013.135

[6] ENVERT, GREAVES M Loops, lineage, and leukemia. Cell 1998; 94: 9-12. http://dx.doi.org/10.1016/S0092-8674(00)81215-5

[7] TENEN DG Disruption of differentiation in human cancer: AML shows the way. Nature reviews. Cancer 2003; 3: 89-101. http://dx.doi.org/10.1038/nrc989 
[8] SPECK NA, GILLILAND DG Core-binding factors in haematopoiesis and leukaemia. Nature reviews. Cancer 2002; 2: 502-513. http://dx.doi.org/10.1038/nrc840

[9] KERSEY JH Fifty years of studies of the biology and therapy of childhood leukemia. Blood 1997; 90: 4243-4251.

[10] BIONDI A, CIMINO G, PIETERS R, PUI CHBiological and therapeutic aspects of infant leukemia. Blood 2000; 96: 24-33.

[11] VAN DER VELDEN VHJ, HOCHHAUS A, CAZZANIGA G, SZCZEPANSKI T, GABERT J et al. Detection of minimal residual disease in hematologic malignancies by real-time quantitative PCR: principles, approaches, and laboratory aspects. Leukemia 2003; 17: 1013-1034. http://dx.doi.org/ 10.1038/sj.leu.2402922

[12] FEARS S, VIGNON C, BOHLANDER SK, SMITH S, ROWLEY JD et al. Correlation between the ETV6/CBFA2 (TEL/AML1) fusion gene and karyotypic abnormalities in children with B-cell precursor acute lymphoblastic leukemia. Genes, chromosomes \& cancer 1996; 17: 127-135. http:// dx.doi.org/10.1002/(SICI) 1098-2264(199610)17:2<127::AIDGCC8>3.0.CO;2-7
[13] GABERT J, BEILLARD E, VAN DER VELDEN VH, BI W, GRIMWADE D et al. Standardization and quality control studies of, real-time' quantitative reverse transcriptase polymerase chain reaction of fusion gene transcripts for residual disease detection in leukemia - a Europe Against Cancer program. Leukemia 2003; 17: 2318-2357. http://dx.doi.org/10.1038/sj.leu.2403135

[14] PAKAKASAMA S, KAJANACHUMPOL S, KANJANAPONGKUL S, SIRACHAINAN N, MEEKAEWKUNCHORN A et al. Simple multiplex RT-PCR for identifying common fusion transcripts in childhood acute leukemia. International journal of laboratory hematology 2008; 30: 286-291. http:// dx.doi.org/10.1111/j.1751-553X.2007.00954.x

[15] BENE MC, CASTOLDI G, KNAPP W, LUDWIG WD, MATUTES E et al. Proposals for the immunological classification of acute leukemias. European Group for the Immunological Characterization of Leukemias (EGIL). Leukemia 1995; 9: 1783-1786.

[16] SKORVAGA M, NIKITINA E, KUBES M, KOSIK P, GAJDOSECHOVA B et al. Incidence of common preleukemic gene fusions in umbilical cord blood in Slovak population. PLoS ONE 2014; 9. 